\title{
Variability of Local Corrosion Attack Morphology of AISI 316Ti Stainless Steel in Aggressive Chloride Environment
}

Viera Zatkalíková, Lenka Markovičová, Juraj Belan, Tatiana Liptáková

Faculty of Mechanical Engineering, University of Žilina, Univerzitná 1, 01026 Žilina, Slovakia. E-mail: viera.zatkalikova@fstroj.uniza.sk, lenka.markovicova@fstroj.uniza.sk,juraj.belan@fstroj.uniza.sk, tatiana.liptakova@fstroj.uniza.sk

\begin{abstract}
AISI 316Ti is Cr-Ni-Mo austenitic stainless steel stabilized by $\mathrm{Ti}$, recommended for construction of various industrial and medicine devices. In spite of its high Pitting Equivalent Resistance Number (PREN=23.688) it underlies local corrosion namely pitting in aggressive chloride environment. Appearance and extent of AISI 316Ti corrosion damage in a particular chloride solution depends strongly on temperature and surface treatment. One part of tested specimens is surface untreated the second part is treated by nitric acid passivation. Specimens are immersed for 24 hours at the temperatures of 30,50 and $80{ }^{\circ} \mathrm{C}$ in $0.3 \mathrm{M} \mathrm{FeCl}_{3}$ solution to induce pitting. Pitting corrosion morphology (shape and size of corrosion pits) is observed viewed from above and in profile as well, by optical metallographic microscope and scanning electrone microscopy SEM. Shape and size of corrosion pits is compared in dependence on temperature and surface finish of specimens.
\end{abstract}

Keywords: Pitting corrosion morphology, AISI 316Ti stainless steel, Immersion test, Aggressive chloride solution, Nitric acid passivation

\section{Acknowledgement}

The research was supported partially by Scientific Grant Agency of Ministry of Education, Science and Sport of Slovak Republic and Slovak Academy of Science grant VEGA No. 1/0485/12 and by project ITMS 26110230117

\section{References}

[1] LIPTÁKOVÁ, T. (2009). Bodová korózia nehrdzavejúcich ocelí (Pitting corrosion of stainless steels), pp. 11 13, EDIS - Žilinská univerzita, Žilina.

[2] SZKLARSKA - SMIALOWSKA, Z. (2005). Pitting and crevice corrosion, pp. 12 - 25, NACE International, Houston, Texas.

[3] GRZEGORZ KROLCZYK, G., LEGUTKO, S. (2013). The Machinability of Duplex Stainless Steel - Solutions in Practice. In: Manufacturing Technology, Vol. 13, No. 4, pp. 473- 478.

[4] KUŚMIERCZAK, S., SVOBODOVÁ, J. (2012). Microscopic Evaluation of Protective Coating by Coated Sheets after Corrosion Load. Manufacturing Technology, Vol. 12, No. 13, pp. 151-157.

[5] KHATTAK, H. S. - RAJ, B. (2002). Corrosion of Austenitic Stainless Steels, Mechanism, Mitigation and Monitoring, pp. 9 - 27, ASM International, Ohio.

[6] LAYCOCK, N. J., NEWMAN, R. C. (1998). Temperature dependence of pitting potentials for austenitic stainless steels above their critical pitting temperature. In: Corros. Sci., Vol. 40, pp. 887-902.

[7] ERNST, P., MOAYED, M.H. LAYCOCK, N. J. NEWMAN, R. C. (1997). Shapes of corrosion pits in metals. In: Electrochemical proceedings, Vol. 97 - 7, pp. $176-185$.

[8] JIANG, Y., SUN, T. XU, J. (2014). Evaluation of Pitting Behavior on Solution Treated Duplex Stainless SteeIUNSS31803. In: J. Mater. Sci. Technol., 30(2), pp. $179-183$.

[9] ZATKALÍKOVÁ, V., BUKOVINA, M., ŠKORÍK, V. PETREKOVÁ, L. (2010). Pitting corrosion of AISI 316 Ti stainless steel with polished surface. In: Materiálové inžinierstvo (Materials Engineering), Vol. 2/2010, pp. 15-19, Žilina.

[10] MALIK, A. U., SIDDIQI, N.A., AHMAD, V., INDIANI, I. N. (1995). The effect of dominant alloy additions on the corrosion behavior of some conventional and high alloy stainless steels in seawater. In: Corros. Sci., Vol. 37, pp. $1521-1535$.

[11] www.italinox.sk (11. 4. 2013) 
[12] DA-CUNHA-BELO, M., RONDOT, B., COMPERE, C., MONTEMOR, M.F., SIMOES, A. M. P., FERREIRA, M. G. S. (1998). Chemical composition and semiconducting behavior of stainless steel passive films in contact with artificial seawater. In: Corros. Sci., Vol.40, pp. 481-494.

[13] BABOIAN, R. (1995). Corrosion Test and Standards: Aplication and Interpretation, ASTM Manual Series, Philadelphia, USA, PA 19103.

[14] HADZIMA, B., LIPTÁKOVÁ, T. (2008). Základy elektrochemickej korózie kovov (Fundamentals of electrochemical corrosion of metals), EDIS - Žilinská univerzita, Žilina, pp. 91-94.

Copyright $($ 2014. Published by Manufacturing Technology. All rights reserved. 